\title{
Clinical application of a superficial layer of the mylohyoid muscle during bone augmentation: A case report
}

\author{
Min-Cheol Yang' ${ }^{1}$, Seong-Joong Park², Won-Pyo Lee³, and Byung-Ock Kim ${ }^{4 *}$ \\ ${ }^{1}$ Doctor of Dental Clinic, Woori Dental Office, Gwangju, Republic of Korea \\ ${ }^{2}$ Resident, Department of Periodontology, Chosun University Dental Hospital, Gwangju, Republic of Korea \\ ${ }^{3}$ Assistant Professor, Department of Periodontology, Chosun University Dental Hospital, Gwangju, Republic of Korea \\ ${ }^{4}$ Professor, Department of Periodontology, Chosun University Dental Hospital, Gwangju, Republic of Korea
}

\begin{abstract}
Guided bone regeneration is a reliable technique used to augment deficient alveolar bone defects. Soft tissue management is one of the several critical factors involved in the bone augmentation procedure. It is very dangerous to extend the lingual flap without creating tension owing to the presence of anatomical structures, particularly in the lower posterior region. Here, we report a method, where the lingual flap is advanced further using the mylohyoid muscle for primary wound closure in the augmented area (lower posterior edentulous region).
\end{abstract}

Key Words: Alveolar ridge augmentation, Mylohyoid, Wound healing

(c) This is an open-access article distributed under the terms of the Creative Commons Attribution Non-Commercial License (http://creativecommons.org/licenses/by-nc/4.0) which permits unrestricted noncommercial use, distribution, and reproduction in any medium, provided the original work is properly cited.

\section{Introduction}

치아가 발거되면 치조제는 흡수된다[1]. 치아가 발거될 경 우 첫 6개월 동안에 치조정 부위에서 수평으로 60\%, 수직으로 $40 \%$ 가 흡수되며, 원래 발치와 폭의 $50 \%$ 가 흡수되면 적절한 임 플란트를 식립하기 어렵다고 보고되었다[2]. 치조제 흡수는 다 발골 소실 때문에 발생되며 구개골 또는 설측골에 비해 협측골 이 더 빨리 흡수된다고 보고되었다[3]. 따라서, 발치 후 시간이 경과된 후에 임플란트를 식립할 때에는 골유도재생술과 같은 고난도의 술식이 필연적으로 동반하게 된다.

하악 후방부위에서 무치악 치조제가 심하게 흡수되어 적절한 크기의 임플란트를 식립할 수 없을 때는 수평 또는 수직 골증대 술을 시행하여야 한다. 이런 골증대술을 시행할 때 골이식재와
차폐막이 노출되는 방지하기 위해 연조직 처치는 매우 중요한 요소가 된다.

임상에서 자주 경험하는 것처럼 하악 후방 부위에서 수직 또 는 수평 골증대술을 하면서 긴장감없는 봉합을 하기 위하여 수 직절개를 시행할 경우 혈관손상에 의한 출혈과 치유 지연, 봉합 의 어려움, 수술시간 지연 등의 여러 문제점이 발생될 수 있다. 또한, 설측판막에 골막이완절개를 시행할 경우 설신경의 손상 및 설동맥의 출혈로 인한 심각한 합병증이 발생할 수 있으며, 협 측판막에 골막이완절개를 하여 봉합할 경우 구강전정이 얕아질 수 있어 향후 임플란트 주위 질환의 발생 위험성이 높아질 수 있 으므로, 이를 극복할 수 있는 대안이 필요하다.

이에 저자들은 하악 후방 부위의 무치악 부위에서 치조골증 대술을 시행한 후 긴장감 없는 봉합을 시행하기 위한 방법으로

Received November 11, 2020; Revised November 29, 2020; Accepted November 30, 2020

*Corresponding author: Byung-Ock Kim, Department of Periodontology, Chosun University Dental Hospital, 303 Pilmun-daero, Dong-gu, Gwangju 61452, Republic of Korea.

Tel: +82-62-220-3850, Fax: +82-62-224-4664, E-mail: bobkim@chosun.ac.kr

Copyright @ 2020, Oral Biology Research Institute 
서 악설골근 표층(superficial layer of mylohyoid bone)을 이 용하는 치관신전설측판막(coronally advanced lingual flap, CALF) 술식을 보고하고자 한다.

\section{Case}

\section{악설골근의 해부학}

악설골근은 반대쪽의 근육과 함께 구강의 바닥을 형성하는 근육으로, 하악체 안쪽면에 있는 악골설골근선(mylohyoid line) 에서 일어나 설골체(body of hyoid bone) 앞면의 아랫부분과 정중섬유솔기(Median fibrous raphe)로 닿는다[4].

악설골근의 최후방부위는 구후융기(retromolar pad) 직하방 에 있는 설측조면(lingual tuberosity)로부터 기시한다. 대구치 부위에서는 악설골근이 점막에 가깝게 부착되어 있으나 소구치 부위에서는 그 부착 부위가 급격하게 하방으로 내려간다. 이러 한 이유 때문에, 대구치 부위에서는 악설골근의 부착부위를 박 리시켜 설측판막이 치관방향으로 부가적으로 확장되는 것이 용 이하게 된다[5].

\section{수술방법}

악설골근은 설측판막을 치관방향으로의 전위에 관여하는데, 이 근육의 표층(superficial layer)은 대구치 부위에서 판막의 기 저부에 존재한다. CALF 술식을 하기 위해서, 침윤 또는 전달마 취 후에 구후융기부터 제 1 소구치 부위까지 치조정 절개를 한다. 이때 소구치부에 치아가 있을 경우에는 열구절개를 시행한다. 악설골근선까지 전층의 설측판막을 거상시키면 이 표층을 관찰 할 수 있다. 핀셋으로 판막을 치관 및 설측방향으로 부드럽게 잡 아당기면서 골막기자의 볼록한 면으로 가볍게 쓸어주는 동작 (brushing motion)으로 긁어주면 악설골근으로부터 이 표층을 쉽게 분리할 수 있다. 이런 과정을 통해서 설측판막을 $10 \mathrm{~mm}$ 내지 $15 \mathrm{~mm}$ 까지는 치관방향으로 신전시킬 수 있다(Fig. 1) [6].

\section{증례}

이 환자는 하악 좌, 우측 제 1 대구치의 무치악부위가 골양과 골질이 불량하여 골유도재생술을 의뢰받은 증례(남자, 54세)로, 이 환자는 담배를 피우지 않았으며 전신건강상태가 양호하였다 (Fig. 2).

국소마취를 한 후 악설골근이 부착되어 있는 구후융기에서부
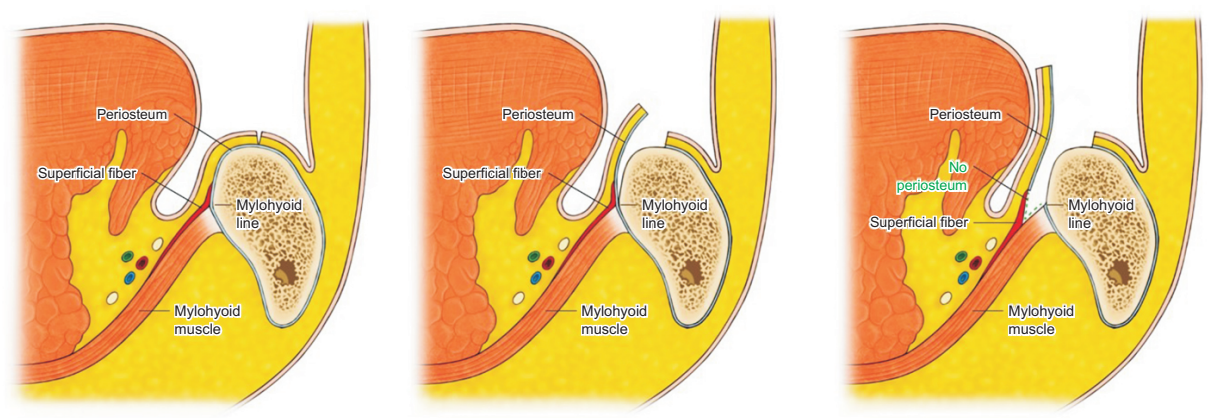

Fig. 1. Drawingshowing the coronally advanced lingual flap procedure at the 1st molar area. (A) Once a full-thickness lingual flap has been elevated up to the mylohyoid line, the attachment of the superficial fibers at the base of the flap can be seen. (B) By gently advancing the flap coronally and lingually, the periosteum at the base of the flap can easily elevated and superficial fiber from the main body of the muscle can be separated with periosteal elevator. (C) This technique allows for a coronal advancement of the flap up to 10 to 15 mm. Modified from the Rossetti. Surgical anatomy of the lingual flap in guided bone regeneration procedures: report of three cases. Poster at SIO, 2013, Milan [6].
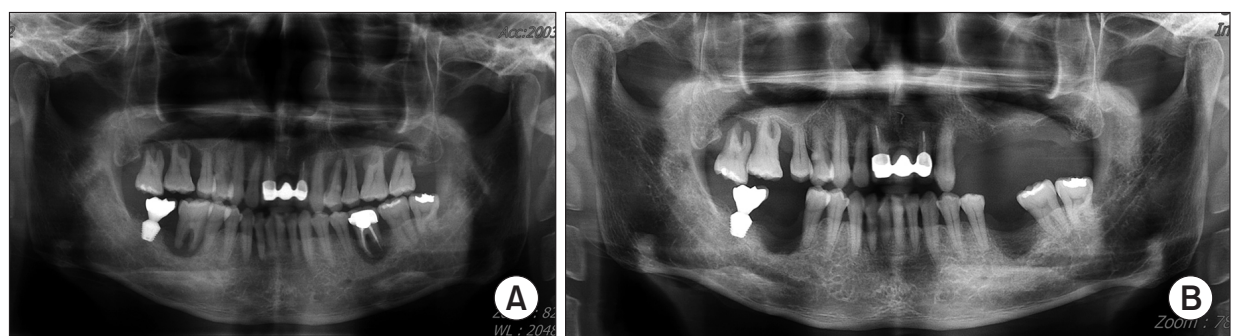

Fig. 2. Preoperativepanoramic view. Note the bone defect aroundthe mandibular right and left first molar area. 
터 제1소구치까지 절개한 후 설측판막을 골막을 포함하여 악설 골근선까지 거상하였는데 $8 \mathrm{~mm}$ 까지 거상되었다(Fig. $3 \mathrm{~A}, \mathrm{~B}$ ). 설측판막을 핀셋으로 잡고 치관 및 설측방향으로 들어 올리면 서 골막기자를 이용하여 가볍게 쓸어주는 동작으로(Fig. 3C) 악 설골근의 표층을 박리시키는 CALF 술식을 시행한 후에는 설측 판막을 $15 \mathrm{~mm}$ 까지 거상시킬 수 있었다(Fig. 3D). 동종골과 비 흡수성 차폐막을 이용한 골유도재생술을 시행한 후 긴장감 없 는 봉합을 시행하였다(Fig. 3E, F).

하악 좌측 제 1 대구치의 경우에는 CALF 술식을 시행하기 전 에는 설측판막을 $9 \mathrm{~mm}$ 까지 거상하였고 이 술식을 시행한 후에 는 설측판막을 $15 \mathrm{~mm}$ 까지 거상시킬 수 있었다(Fig. $4 \mathrm{~A}, \mathrm{~B})$. 치 유기간 동안 연조직은 양호하게 치유되어 이식된 골조직도 잘

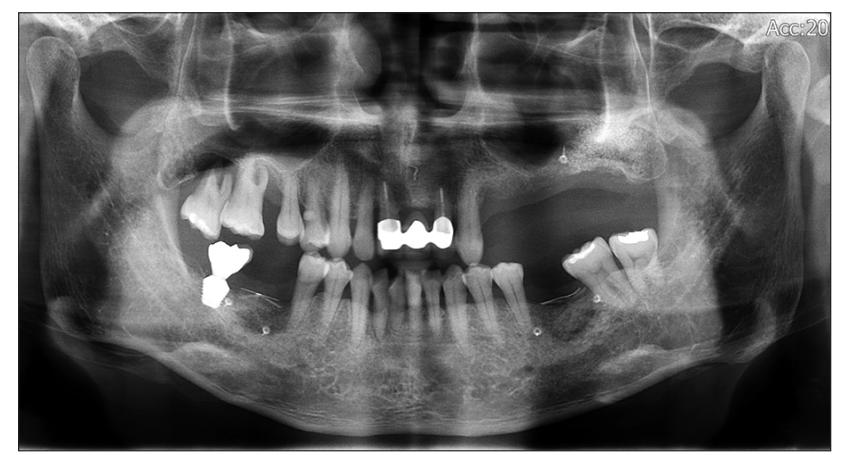

Fig. 5. Postoperative panoramic view.
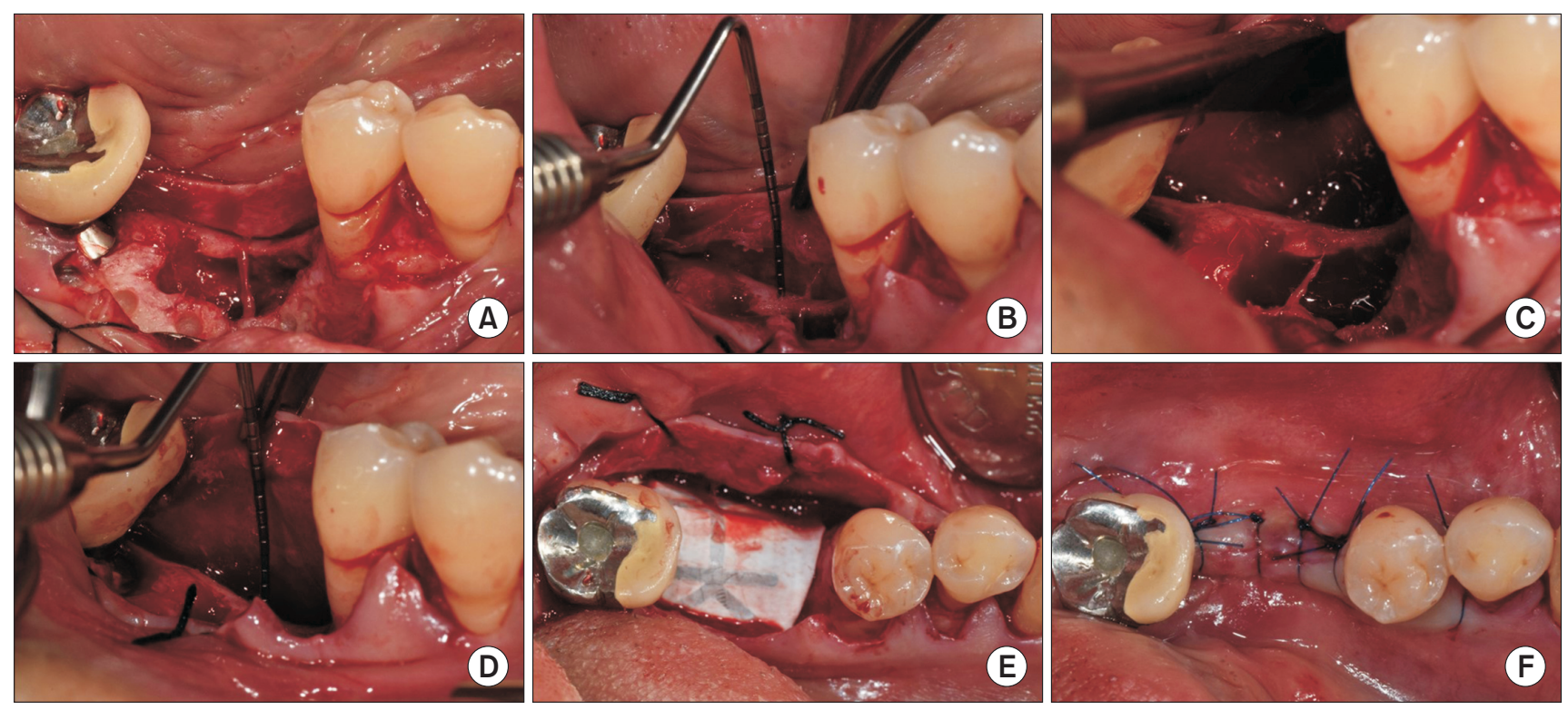

Fig. 3. Case of a patient treated with the coronally advanced lingual flap procedure in the mandibular right first molar area. (A) Large, unhealed extraction socket. (B) A $8 \mathrm{~mm}$ of flap extension before the coronally advanced lingual flap procedure. (C) Superficial fiber from the main body of the muscle being separated with periosteal elevator (brushing motion). (D) A $15 \mathrm{~mm}$ of flap extension after the coronally advanced lingual flap procedure. (E) Occlusal view of non-Resorbable membrane securedover the defect area. (F) Primary closure of the flaps without tension.
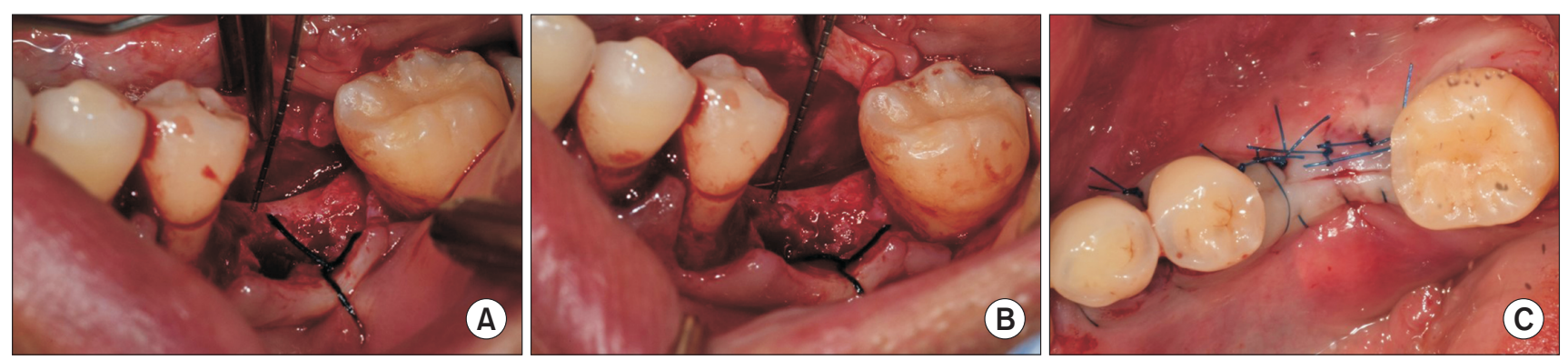

Fig. 4. (A, B) A $9 \mathrm{~mm}$ and $15 \mathrm{~mm}$ of flap extension before and after coronally advanced lingual flap procedure in the mandibular left molar area, respectively. (C) Primary closure of the flaps without tension. 
유지되고 있었다(Fig. 5).

\section{Discussion}

Dahlin 등 [7]이 쥐의 하악골에 만들어진 골결손부가 조직유 도재생술식을 사용하여 성공적으로 치유된 것을 보고한 이래로 골유도재생술에 관련된 많은 수술방법이 발표되었다.

Wang과 Boyapati [8]는 골유도재생술에 필요한 생물학적 원 칙으로 (1) 창상의 일차폐쇄, (2) 미분화된 간엽세포와 혈관공급 을 위한 혈관형성, (3) 골유입에 필요한 공간확보/유지, 그리고 (4) 초기혈전과 임플란트의 안정성 등을 보고하였다. 특히, 창상 의 일차폐쇄는 세균의 내부 함입을 막아주고 조직의 개조와 재 형성을 위해서 필요한 기본적인 원칙에 속한다. 창상의 일차폐 쇄를 얻기 위해서는 판막을 긴장감 없이 봉합해야 한다[9].

긴장감 없는 창상폐쇄를 위한 방법으로 골막절개를 넓게 형 성하는 방법[10], 수직절개와 골막절개를 이용하는 방법[11], 레 이저를 이용한 골막절개법[12], 그리고 수술 범위가 넓고 큰 경 우에는 수직절개와 2개의 골막절개를 이용하는 방법[13] 등이 보고되었는데, 일반적으로 치조점막에서 부분층 판막을 형성하 여 판막을 신전시킨다.

이 증례보고의 목적은 하악 후방 부위에서 치조제 결손이 심 하여 골증대술만 또는 임플란트 식립과 동시에 골증대술이 필 요한 경우에 창상의 일차폐쇄를 쉽게 얻을 수 있는 방법을 소개 하는 것이다.

이 증례는 임플란트를 식립할 경우 1차 고정을 얻을 수 없 을 정도로 잔존 치조골의 높이가 적었으며 발치와가 넓었고 치 조제가 수직으로 흡수되어 있는 경우로, 발치와 보존술과 무치 악부위에 인접한 치간골 높이까지 약간의 골증대술이 필요하 였다. 무치악에 인접한 치간골도 상당히 흡수되어 수직으로 많 은 양의 골증대를 할 필요가 없었으나 비흡수성차폐막의 노출 을 예방하고 협측판막의 골막이완절개에 의한 구강전정이 얕아 지는 것을 최소화하기 위해 CALF 방법을 선택하게 되었다. 통 법에 의해 설측판막을 악설골근선까지 전층판막으로 거상한 다 음, 판막 내면을 골막기자의 볼록한 면으로 가볍게 쓸어주는 동 작(brushing motion)을 반복함과 동시에 판막을 치관방향과 내 측으로 들어올리면 악설골근 본체로부터 악설골근 표층이 분리 되어 각각 $6 \mathrm{~mm}$ 와 $7 \mathrm{~mm}$ 까지 판막을 신전시킬 수 있었다.

이 술식의 장점은 설측의 전층판막에 골막이완절개를 하지 않으므로 설측에 분포되어 있는 중요한 해부학적 구조물에 대 한 손상을 감소시키면서 판막을 충분히 신전시킬 수 있다는 것 이다. 또 다른 장점으로, 통상적인 수직절개와 협측판막의 골막 이완절개를 했을 때 발생될 수 있는 출혈 또는 판막 천공의 위험 성을 감소시킬 수 있고 수술시간을 감소시킬 수 있다는 점을 들
수 있다. 이 수술을 받은 환자들 중에서 구강저가 올라와 약간 불편한 느낌을 호소하였으나 소염 - 진통제를 복용하고 치유시 간이 지남에 따라 불편감은 자연적으로 해소되었다.

이 CALF 술식은 하악 후방부위의 무치악 치조제가 심하게 흡 수되어 수평 또는 수직골증대술이 필요한 경우에 악설골근의 표층을 이용하여 설측판막만을 신전시켜 창상의 일차폐쇄를 얻 을 수 있으므로 임상에 큰 도움이 되리라 생각된다.

\section{Acknowledgements}

This study was supported by research fund from Chosun University Dental Hospital, 2019.

\section{Conflicts of Interest}

The authors declare that they have no competing interests.

\section{ORCID}

\author{
Min-Cheol Yang \\ http://orcid.org/0000-0002-4168-2402 \\ Seong-Joong Park \\ http://orcid.org/0000-0002-5642-8108 \\ Won-Pyo Lee \\ http://orcid.org/0000-0003-1911-3454 \\ Byung-Ock Kim \\ http://orcid.org/0000-0001-8952-617X
}

\section{References}

1. Agarwal G, Thomas R, Mehta D. Postextraction maintenance of the alveolar ridge: rationale and review. Compend Contin Educ Dent 2012;33:320-324, 326; quiz 327, 336.

2. Wang RE, Lang NP. Ridge preservation after tooth extraction. Clin Oral Implants Res 2012;23 Suppl 6:147-156. doi: 10.1111/j.1600-0501.2012.02560.x.

3. Araújo MG, Sukekava F, Wennström JL, Lindhe J. Ridge alterations following implant placement in fresh extraction sockets: an experimental study in the dog. J Clin Periodontol 2005;32:645-652. doi: 10.1111/j.1600-051X. 2005.00726.x.

4. Kim MK. Head and neck anatomy. 6th ed. Seoul: Dental \& Medical Publishing; 2017;269.

5. Ronda M, Stacchi C. Management of a coronally advanced lingual flap in regenerative osseous surgery: a case series introducing a novel technique. Int J Periodontics Restor- 
ative Dent 2011;31:505-513.

6. Rossetti P. Rossetti P. Surgical anatomy of the lingual flap in guided bone regeneration procedures: report of three cases [Internet]. Poster at SIO, 2013, Milan [cited 2020 Oct 21]. Available from: http://www.deorematerials.com/ wordpress/wp-content/uploads/2013/02/POSTER-LOWRESOLUTION.pdf

7. Dahlin C, Linde A, Gottlow J, Nyman S. Healing of bone defects by guided tissue regeneration. Plast Reconstr Surg 1988;81:672-676. doi: 10.1097/00006534-19880500000004 .

8. Wang HL, Boyapati L. "PASS" principles for predictable bone regeneration. Implant Dent 2006;15:8-17. doi: 10.1097/01.id.0000204762.39826.0f.

9. Romanos GE. Periosteal releasing incision for successful coverage of augmented sites. A technical note. J Oral Implantol 2010;36:25-30. doi: 10.1563/AAID-JOID-09-00068.
10. Kim Y, Kim TK, Leem DH. Clinical study of a flap advancement technique without vertical incision for guided bone regeneration. Int J Oral Maxillofac Implants 2015;30:11131118. doi: 10.11607/jomi.3586.

11. Park JC, Kim CS, Choi SH, Cho KS, Chai JK, Jung UW. Flap extension attained by vertical and periosteal-releasing incisions: a prospective cohort study. Clin Oral Implants Res 2012;23:993-998. doi: 10.1111/j.1600-0501.2011.02244.x.

12. Moslemi N, Khorsand A, Torabi S, Shahnaz A, Soleimani Shayesteh Y, Fekrazad R. Periosteal releasing incision with diode laser in guided bone regeneration procedure: a case series. J Lasers Med Sci 2016;7:259-264. doi: 10.15171/ jlms.2016.46.

13. Ogata Y, Griffin TJ, Ko AC, Hur Y. Comparison of doubleflap incision to periosteal releasing incision for flap advancement: a prospective clinical trial. Int J Oral Maxillofac Implants 2013;28:597-604. doi: 10.11607/jomi.2714. 